\title{
What a Feeling? In Search of a Metaphysical Connection between Panpsychism and Panentheism
}

\author{
Uwe Voigt
}

\section{Introduction}

What has been said about the relation between panpsychism and pantheism ${ }^{1}$ seems to hold also for panpsychism and panentheism: They are logically independent from one another. At least, a panpsychist universe without panentheist background can be conceived of without any contradiction. This paper is going to pursue the following question: Could it nevertheless be the case that there is a metaphysical connection between panpsychism and panentheism?

This question brings to mind what might be a parallel case, famously argued for by Saul Kripke ${ }^{2}$ : Before the advent of modern chemistry, the question about the essence of water could be, and has been, answered in several ways. In the meantime, the microstructure of water, described by the formula $>\mathrm{H}_{2} \mathrm{O}<$, turned out to be a promising candidate for a metaphysical truth about what water essentially is, insofar our natural kind term >water< rigidly designates the stuff with that microstructure throughout all possible worlds. Logic alone could not provide this connection; it was forged by experience - in this case scientific experience within a certain theoretical framework.

Can a metaphysical connection between panpsychism and panentheism be established in a similar way? This question encounters the problem that panpsychism seems to be a position which it is at least not directly corroborated by experience ${ }^{3}$. But maybe the according experience has just not yet been identified as such. In this paper the following will be argued: Panpsychism can refer to such an experience, the experience of what it is like to be a natural subject. As in the case of water, there is a framework within which this experience can be elucidated, namely a phenomenological approach suggesting that subjects are open to (mental) atmospheres which can connect them. To pursue this line of thought, it is apt to begin with a look at panpsychism.

1 Cf. Leidenhag 2018: Introduction.

2 Cf. Kripke 1980.

3 Cf. e.g. Brüntrup/Jaskolla 2017b: 4; Goff 2017a: 283 f.

(C) UWE VOIGT, 2020 | DOI:10.30965/9783957437303_009

This is an open access chapter distributed under the terms of the CC BY-NC-ND 4.0 license. Voigt - 9783957437303 


\section{A Look at Panpsychism}

For the newly gained prominence of panpsychism in contemporary philosophy, especially in analytic philosophy of mind, the following reasons can be given:

$\left(\mathrm{R}_{1}\right)$ Subjects are entities which can be in specific, namely mental, phenomenal or conscious ${ }^{4}$, states, i.e., in the following sense ${ }^{5}$ : Subjects have perspectives on the world (intentionality), and it is like something for them to have these perspectives (qualitative consciousness).

$\left(R_{2}\right)$ There are subjects which have been brought about in the course of natural evolution. Such subjects are to be called macrosubjects.

$\left(R_{3}\right)$ The entities grasped by physics are just dispositional structures lacking intentionality and qualitative consciousness ${ }^{6}$.

$\left(\mathrm{R}_{4}\right)$ Only something which has intentionality and qualitative consciousness, namely some kind of subject or at least something which is subjective, is sufficient to bring about something which has these very properties?

$\left(\mathrm{R}_{5}\right)$ Therefore macrosubjects have to be been brought about by something like a subject or by other subjects. Such subjects are called microsubjects.

$\left(\mathrm{R}_{6}\right)$ Microsubjects (at least at the fundamental level of reality given by physics) are the qualitative inside of the dispositional structures grasped by physics $^{8}$.

These reasons are well-founded:

$\left(\mathrm{R}_{1}\right)$ sums up a concept issued during the last decades in defense against physicalist attacks on subjectivity. This concept has been developed, among others, by Thomas Nagel and David Chalmers and stresses that intentionality and phenomenal consciousness as essential properties of subjectivity are not within the object realm of physics and therefore cannot be denied in the name of a physical worldview by physicalism ${ }^{9}$. Being thus theoretically motivated, this thesis can refer to each and every one's personal experience at the same time and therefore is hard to shake.

$\left(\mathrm{R}_{2}\right)$ is based on the wide-spread and well-founded conviction that there are at least human subjects and that these subjects have been brought about in

4 In this paper, like in the panpsychist literature referred to below, these terms will be handled as synonymous.

5 Cf. Voigt 2019: 41-43.

6 Cf. Brüntrup/Jaskolla 2017c: 926-928, Chalmers 2017a: $26 f$.

7 Cf. Brüntrup/Jaskolla 2017b: 3 .

8 Cf. ibid.

9 Cf. Brüntrup/Jaskolla 2017c: 923-928. 
the course of natural evolution. The growing acceptance of subjectivity in the animal kingdom ${ }^{10}$ gives further support to this thesis.

$\left(\mathrm{R}_{3}\right)$ seems to describe quite aptly what contemporary physics is doing and moreover what it should be doing according to its theoretical and empirical foundations ${ }^{11}$.

$\left(\mathrm{R}_{4}\right)$ is a version of the principle of sufficient reason ${ }^{12}$ : If there is such a generic difference between subjects as conceived of in $\left(\mathrm{R}_{1}\right)$ and the objects of physics as given by $\left(\mathrm{R}_{3}\right)$, the bringing about of subjects by objects of physics would be a case of super-strong emergence in which something completely new appears in a way that cannot be accounted for, that remains unintelligible. Panpsychists claim that there is one promising alternative to this, namely that some subjects (macrosubjects) are brought about by other subjectsaccording to $\left(\mathrm{R}_{5}\right)$. Generally: Subjectivity can arise only from subjectivity. This is what makes subjectivity another basic feature of reality, besides or more precisely, as the look on $\left(\mathrm{R}_{5}\right)$ will show, inside the physical features. How intelligible this suggestion really is remains contested, as a look at the combination problem will show below.

$\left(\mathrm{R}_{5}\right)$, the claim that there are microsubjects or something like them, follows logically from these presuppositions. »Microsubjects or something like them « here hints to the demarcation lines between different kinds of panpsychism and related positions: panpsychism proper which will be pursued here and which presupposes that it is subjects all the way down, and other brands which assume that the chain of subjects in some place breaks off in favor of somehow subjective entities which nevertheless are not subjects themselves, but rather experiences or qualities ${ }^{13}$. Panpsychism proper is preferred here for two reasons: In the first place, it is hard to conceive of something subjective without any subject experiencing it; in the second place, the progress towards >reak subjects would have to be a case of super-strong emergence, a >brute< occurrence which to avoid is prudent whenever possible.

$\left(\mathrm{R}_{6}\right)$ is an attempt to find a place in nature for these microsubjects. One such place, also in a non-metaphorical sense, is supposed to be found inside the fundamental objects of physics, whatever these may be. This move guarantees that panpsychist theses do not get into conflict with physics, which, according to (3) does not have anything to say about these insides and rather is occupied only with the structural dispositions obtaining between them.

\footnotetext{
10 Cf. Soentgen 2018: 36-42.

11 Cf. Goff 2017b: 23-39.

12 On this and the follwing cf. Brüntrup 2017.

13 Cf. Chalmers 2017a, Goff 2017c: 165-171.
} 
As these points show, panpsychism tries to overcome physicalism and at the same time to access to its inheritance, physicalism being the thesis that the entities grasped by physics are sufficient to bring about subjects. Panpsychism tries to overcome physicalism by denying this thesis (which has come under great pressure anyway), and tries to access to the inheritance of physicalism by keeping up the notion that there are levels of reality given by physics, and that these levels - at least one of them-play a crucial role for the rise of macrosubjects. As these levels are levels of nature, panpsychism, like physicalism, still is a naturalism, but a more liberal ${ }^{14}$, one could also say a more inclusive one, as it includes subjectivity already as a fundamental factor of reality.

So panpsychism looks like an attractive solution to the mind-body-problem: According to panpsychism, the relation between mind and body is not mysterious but rather intimate; and situating subjectivity at least on a lowest level of physical reality does not contradict the accepted assumption that science shows us a physical world, for, in a panpsychist view, this world is only the outside of that reality, which also has a mental inside. At the same time, panpsychism makes it plausible how, within such a physical world, >ordinary< subjects ${ }^{15}$ like ours can arise: with a little help of the microsubjects hidden intimately on the inside of that physical world.

\section{The Combination Problem}

This solution, however, comes with a price: If microsubjects do the job to bring about macrosubjects, how do they do it? This question has been posed in the form of the famous combination problem ${ }^{16}$. In its original version by William James this problem starts with the assumption that microsubjects would have to constitute macrosubjects, in the sense of weak emergence, so that microsubjects somehow blend or fuse together in order to form a larger whole, and the contents of the mental states of this whole are accordingly formed by the contents of the mental states which belonged to the smaller units. Subjects and the contents of their mental states, however, just do not seem to do this. Even when put very close to one another, they do not fuse but rather remain enclosed within themselves.

One problem with the combination problem is the weak emergentist view that microsubjects constitute macrosubjects. A promising way out is to give

\footnotetext{
14 Brüntrup/Jaskolla 2017c: 928.

15 Cf. Goff 2017a: 295 .

16 On this and the following cf. the contributions to »Part III. Panpsychism and the Combination Problem« in Brüntrup/Jaskolla 2017a.
} 
up that view. Super-strong emergence also is out of the question, for it would mean that what is brought about belongs to another category than what is bringing it about, while here we deal with subjects on both sides. Moreover, to avoid super-strong emergence is what makes panpsychism excel in its competition with physicalism. What remains is non-constitutive strong emergence ${ }^{17}$. According to it, the microsubjects combine while staying what they are, and through their combination the macrosubjects comes to be as yet another subject. The Whiteheadian formula for this runs: »The many become one and are increased by one ${ }^{18}$, with $>$ becoming one here meaning $>$ getting related to one another and >are increased by one< standing for sthe additional subject, the macrosubject, being synchronically generated by that getting related to one another of the microsubjects<.

This way out, however, encounters a generalized version of the combination problem, »The No Summing of Subjects Argument « ${ }^{19}$ : Even if, or precisely if, microsubjects do not constitute macrosubjects, how can they bring them about after all, since subjects do not seem to be able to ssum< in any way? Philip Goff rightly calls this »the heart of the combination problem $\ll^{20}$, and articulates its presuppositions as follows ${ }^{21}$ :

$\left(\mathrm{CP}_{1}\right)$ »Conceptual Isolation of Subjects «: It is possible to conceive that a certain number of subjects exist with certain mental states and this does not necessitate the existence of another subject.

$\left(\mathrm{CP}_{2}\right)$ »Transparency Conceivability Principle«: If a proposition contains only transparent elements, i.e. elements which reveal what they are about just by inspection, and if, reflected in an ideal way, that proposition can be conceived of to be true, it »is metaphysically possibly true «.

$\left(\mathrm{CP}_{3}\right)$ »Phenomenal transparency«: »phenomenal concepts are transparent «.

$\left(\mathrm{CP}_{4}\right)$ »Metaphysical Isolation of Subjects « (MIS): It follows from the above premises that any number of subjects may exist without necessitating the existence of another subject.

$\left(\mathrm{CP}_{5}\right) \quad \mathrm{CP}_{4}$ has the consequence that subjects cannot bring about other subjects, at least not as panpsychism would have it.

$\left(\mathrm{CP}_{6}\right)$ »Therefore, panpsychism is false.«

$\begin{array}{ll}17 & \text { Cf. Brüntrup 2017. } \\ 18 & \text { Cf. ibid.: } 66 . \\ 19 & \text { Goff 2017a: } 291 . \\ 20 & \text { Ibid. } \\ 21 & \text { Ibid.: 291f. }\end{array}$


In a convincing way, Goff argues for the first four premises and stresses that especially panpsychists should endorse phenomenal transparency, because to him what would make phenomenal concepts intransparent could only be their physical nature which is denied by panpsychism. Nevertheless, Goff still sees a chance for panpsychism to survive this assault: (MIS) only claims that the existence of a certain number of subjects does not necessitate the existence of another subject. It might still be the case that the existence of a certain number of subjects with certain mental states, which in turn have certain phenomenal properties, together with some relation between these mental states necessitates the existence of another subject ${ }^{22}$. A relation of this kind Goff calls >phenomenal bonding «. Goff assumes that, while we can experience the phenomenal properties, we cannot experience the relations between them, which means: we cannot experience phenomenal bonding. Goff traces this back to what he passingly assumes as obvious: that »consciousness is a monadic property «23. From the immediate context, it becomes clear what this $>$ monadic $<$ thesis means to him:

(MON) Each and every mental state is a categorial (i.e. also: non-relational) state of only one subject and therefore can be experienced only by that subject.

According to (MON), phenomenal bonding as a relation between mental states of several subjects cannot be experienced by any subject. Hence phenomenal bonding is not directly observable, yet, as Goff argues, the sciences offer plausible parallel examples that sometimes it makes sense to assume the existence of non-observables ${ }^{24}$.

The concept of phenomenal bonding can be applied both in constitutive and in strongly emergentist panpsychism ${ }^{25}$. Since the latter already has proved to be more promising, it has to be considered what, in its context, phenomenal bonding can mean. In principle, it seems to mean that there are and there remain several microsubjects with their respective mental states and that these mental states are related by their phenomenal properties to one another-are >phenomenally bonded - -so that this relation brings about another subject, the macrosubject of these microsubjects. The macrosubject is added to its microsubjects and, so to speak, exists grounded on the web of

$\begin{array}{ll}22 & \text { Ibid.: } 292 . \\ 23 & \text { Ibid.: } 293 . \\ 24 & \text { Cf. ibid.: } 292 f . \\ 25 & \text { Cf. ibid.: } 295 .\end{array}$


their phenomenal interrelations. This view, however, again raises questions highlighted by David J. Chalmers:

What is the phenomenal bonding relation? And how could any phenomenal relation holding between distinct subjects (or between phenomenal states of distinct subjects) suffice for the constitution of a wholly new subject?26

Chalmers proceeds to answer these questions:

A natural candidate here is the co-consciousness relation: a relation such that whenever it relates two phenomenal states, they are experienced jointly. When this relation holds among the states of distinct microsubjects, those states will be experienced jointly by a new subject. ${ }^{27}$

But he does so only to come up with a new problem arising from this answer: Being a mental phenomenon, on a panpsychist background the $>$ co-consciousness relation $<$ has to be the inside of a physical relation. For microsubjects on the fundamental level of reality, such relations should be fundamental physical relations like spatio-temporal and causal relations. These relations in turn are connected with one another so that, in the final analysis, their network encompasses the whole universe. The problem posed by this can be called limitation problem: Is the co-consciousness relation-principally or within certain ranges - transitive or intransitive. I.e.: Are there, within this cosmic network of mutually linked co-consciousness relations, any lower or upper limits for bringing about new subjects? What makes the limitation problem a problem are the consequences of various ways to answer that question: If the whole network itself is the lower limit, that would mean that the universe is either the only subject (which Chalmers seems to fear ${ }^{28}$ ) or the primary subject (which Goff has come to endorse ${ }^{29}$ ), which would make the existence of >ordinary< subjects like us either epiphenomenal or hard to explain. If every link in that network brings about a new subject, that would mean that there are very many (macro)subjects and it would leave us with only fragmented subjects, which would make it »hard to see how we will get macrosubjects « ${ }^{30}$. And if only certain structures in that network bring about new subjects, we would need a reason why this is so, i.e. why certain groups of links are

26 Chalmers 2017b: 200. It should be noted that >constitution< here is to be understood in such a broad sense that it includes also strongly emergentist panpsychism.

27 Ibid.

28 Ibid.: 201.

29 Id. 2017b: 220-255.

3o Id. 2017a: 201. 
$>$ transitive<, i.e. jointly take part in bringing about a new subject, why others are >intransitive<, i.e. do not take part in doing so.

Chalmers does not exclude »intermediate possibilities in which the relation is just nontransitive enough to yield nontrivial macrosubjects«, but in order to make those possibilities work, it would have to be shown how this structure between microsubjects and macrosubjects can arise so that »a limited multiplicity of microsubjects associated with the human organism « can be assumed, saving the phenomenon of our subjectivity connected with such an organism $^{31}$. An >intermediate possibility< would have to avoid the "Scylla of a universal subject and the Charybdis of fragmentary subjects « ${ }^{32}$. Goff himself goes for the Scylla by »identify[ing] the phenomenal bonding relation with the spatial relation $\aleph^{33}$. At first glance, this move is plausible: Also space is something known to science by its outer, dispositional properties; if such outer properties hint to subjectivity hidden inside of them, this should apply also to the case of space. If one takes the space of the universe to be a continuous whole, as Goff does, this leads to the thesis that there is a universal mind as the inside of the whole spatially extended universe ${ }^{34}$. Whoever is inclined to take the mind of the universe to be divine ends up with some kind of panentheism based on panpsychism right here. Rather, panpsychism understood this way collapses into panentheism. What still makes this horn of the dilemma a »Scylla « hard to embrace, however, is the circumstance that the phenomemon to be savedhuman consciousness-in the very process of its salvation threatens to get lost in space or at least to be turned into an epiphenomenon, something which exists only on a superficial plane of appearance. This contradicts the shard fact< of our existence as subjects; therefore the search for an »intermediate possibility« is justified.

\section{Phenomenal Bonding and New Phenomenology}

A way towards such an option can start from questioning one presupposition which Chalmers and Goff (together with most contemporary panpsychists) share, namely (MON). This presupposition, plausible as it seems to be at first sight, does not only pose an epistemic problem for phenomenal bonding by declaring it unobservable. (MON) challenges phenomenal bonding also ontologically: The relations in which phenomenal bonding itself consists are not

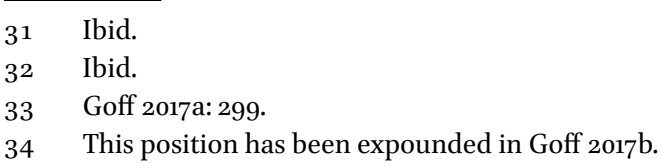


physical relations but rather their non-physical inside. At the same time, according to (MON) those relations are not mental states-not only because they are not states but relations, but also because there is no subject that could experience them, for subjects can only experience their own, non-relational states. Hence, if (MON) is true, phenomenal bonding gets stranded in an ontological no man's land as a type of relation which is neither physical nor mental; it seems to be a leftover from neutral monism ${ }^{35}$, only that the otherwise indeterminable >neutral now is situated within relations rather than within their relata. At best, this is where panpsychism proper would have to end and give way to protopanpsychism or some other position which works with $>$ something like a subject<. If panpsychism proper has to end here, however, it does not even start, because then it would lose the microsubjects on the fundamental level of physical reality it presupposes.

But it does not have to end this way, because (MON) has been challenged in a way that can help out of that predicament. This challenge comes from a philosophical movement which goes under the name of New Phenomenology ${ }^{36}$. Its core thesis has been formulated by its founder Hermann Schmitz ${ }^{37}$ : The phenomenological description of feelings like anxiety, joy and despair shows that they are entities of a certain type which Schmitz calls atmospheres. Atmospheres in this sense are not in the subject but permeate and surround it so that also several subjects may participate in them. Atmospheres according to Schmitz may even be there without any subject feeling them. They qualify as mental states in the minimal sense endorsed also by panpsychism - see $\left(R_{1}\right)$ - , because it is like something to be in them, and they are distinct perspectives on the world, which is sensed differently when in anxiety, joy, despair and so on. Whoever adopts $\left(\mathrm{CP}_{3}\right)$, according to which phenomenal concepts are transparent, and accepts Schmitz's description, has to agree that atmospheres are spatially extended mental states which do not belong to any one subject. This is enough to contradict (MON) by claiming that not all mental states are states of one and just one subject. At the same time, it fits nicely to the thesis that mental states might be spatial relations. Panpsychism and New Phenomenology seem to approach the same position in logical space from different directions. Of course, panpsychism tries to explain the rise of subjectivity in general term and thus is a metaphysical project, while New Phenomenology puts description in the first place, but this need not stop both from being complementary for each other. 
The way New Phenomenology originally was presented by Schmitz, however, threatens to disrupt this rapprochement. Two issues have to be mentioned here: Firstly, Schmitz claims that atmospheres just are there and received by subjects, denouncing any attempt to explain how atmospheres themselves arise as pointless ${ }^{38}$. If this were so, the concepts of atmospheres would be useless for the (also explanatory) project of panpsychism. Secondly, according to Schmitz the space in which feelings are extended is totally different from the space explored by science ${ }^{39}$. Space in the first sense is a $>$ feeling-space< filled by specific kinds of stuff which mediate what is felt in this space and how it is felt. This space lacks dimensions but has - only qualitative-intensities and in some cases directions. Space in the second sense is a neutral medium for intersubjective orientation and filled with the matter quantified by science. If this were so, adopting the concept of space in New Phenomenology to a problem of panpsychism could only rest on an equivocation.

Remarkably, during the further development of New Phenomenology, these two issues have been tackled: As Gernot Böhme has pointed out ${ }^{40}$, concerning the first issue, aesthetic experience shows that there are indeed cases in which atmospheres are generated, for example in artistic efforts. As to the second issue, Jens Soentgen has argued critically that the thesis of the spatiality of feelings is informative only if space in this context is understood as the >ordinary space of intersubjective orientation and scientific exploration; otherwise it would be pointless or at best figurative to talk about a >feelingspace at all ${ }^{41}$. Constructively, Soentgen has elaborated the thesis that >ordinary space is also feeling-space by developing hermeneutic approaches in different fields of the life-sciences ${ }^{42}$. The point of these approaches is: Certain phenomena like the behavior of single organisms but also of complete ecosystems can be explained and also predicted in a more comprehensive way if these phenomena are understood as reactions to atmospheres in the sense of New Phenomenology. For example, it is like something to be wildlife in a wood where regularly hunting takes place. And because the space in which the according mental states are situated is no mysterious medium on its own, but the space also traversed by humans and explored by science, also the stuff mediating feelings throughout space is not just a mysterious non-physical something, but the ordinary stuff known to everyday experience and (in some extent) to

\footnotetext{
38 Cf. id. 1999: 286.

39 Cf. id. 1990: 310-318.

40 Cf. Böhme 1995.

41 Cf. Soentgen 1998: 106.

42 Cf. id. 2018.
} 
science $^{43}$. Against such an identity thesis, Schmitz has argued already early that the stuff feelings are made of displays other properties than the physical stuff ${ }^{44}$. But, as may be learned from panpsychism, categorial distinctness can go hand in hand with intimate ontological connectedness: The way panpsychism sees the physical universe suggests that there is only one category of stuff, of course encompassing different stuffs, which have physical properties on the outside and have mental properties - the way it feels to be confronted with them-as their inside.

This approach in the context of the life-sciences can contribute to solve the limitation problem, centered round the question how we can arrive at macrosubjects like ourselves. In that context, the obvious answer is: by natural evolution. In the course of this evolution, it may happen that many microsubjects become one in the sense that they get phenomenally bonded to one another. On the background of New Phenomenology, that means: They enter an atmosphere which makes them form a certain arrangement that gives rise to a macrosubject. If this macrosubject in turn manages to keep up this atmosphere, it will endure as such. Being an enduring subject and therefore being capable of consciousness will provide enhanced abilities to react to the environment. By the ensuing increase of the fitness of their members, whole species of organisms with macrosubjects may arise - and obviously have arisen. All of this does not presuppose any intention to make this happen on the side of the microsubjects or the macrosubjects; it rather happens to them, and it could not be any other way, because having and carrying out such an intention would presuppose rationality; but the microsubjects, as may be assumed in this case, are not rational at all, and some macrosubjects may be rational, and are in the case of human subjects, but come to exist as such only through the act of phenomenal bonding which therefore must precede the exercise of their own rational capabilities ${ }^{45}$.

If phenomenal bonding is a spatial relation mediated by the qualities of certain kinds of stuff, and if being a subject and thus being capable of consciousness offers an advantage in the struggle for survival ${ }^{46}$, those species have a great benefit whose exemplars are macrosubjects which manage it to bring about stable phenomenal bonding of their microsubjects. Neither on the side of the microsubjects nor on the side of the macrosubject this is an intended

\footnotetext{
43 Cf. id. 2019.

44 Cf. Schmitz ${ }^{2}$ 1981: 208.

45 Cf. Voigt 2019: 54f.

46 Cf. Meixner 2004: 81; Swinburne 2007: 180-183. The point of consciousness as evolutionary advantage has been made by two dualists, but it can be used by panpsychists as well.
} 
process; rather it is something which happens and keeps itself happening while it is happening.

\section{A Metaphysical Connection between Panpsychism and Panentheism}

A further elaboration would have to show on which levels and under which physical, chemical and biological circumstances subjects can get phenomenally bonded in according atmospheres. That elaboration itself lies out of the scope of this paper. But within it lies the question asked at its beginning: Could there be a metaphysical connection between panpsychism and panentheism mediated by an experience? This question now can be reformulated: Can panentheism give an answer to a question which does not concern the circumstances under which, but the reason why subjects get phenomenally bonded in according atmospheres. The problem behind this question is: For subject to get bonded that way, the according atmospheres already have to exist, have to address them. Where, then, do that atmospheres come from? Seen from the outside, as modern science might do, it could seem that these atmospheres arise by mere chance. In the course of natural evolution, microsubjects undergo many kinds of mutual arrangements; some of these arrangements, maybe highly improbable, but not impossible, bring about the right kinds of atmospheres; the resulting macrosubjects somehow manage to sustain these atmospheres; and the rest, like all of it before, is evolutionary history. But what it this process like viewed from the inside? The view from the outside cannot exclude that the microsubjects are somehow addressed and thereby motivated to enter those arrangements. As Brüntrup and Jaskolla have shown ${ }^{47}$, such a speculative, but plausible consideration about the view from the inside demonstrates how panpsychism in general can underwrite a theist view of the world, with God not forcing, but nudging the microsubjects into a development towards increasing completion which includes the bringing about of macrosubjects. For this, there is again a fitting Whiteheadian catchphrase, depicting God as »the lure for feeling « 48 . Having panpsychism enriched with motives from New Phenomenology, this can be understood in the following way: God >lures< the microsubjects to form the mentioned arrangements by offering them an anticipation of the atmosphere they are going to enter in order to bring about a macrosubject.

47 Cf. Brüntrup/Jaskolla 2017c: 929-943.

48 Ibid.: 941. 
Brüntrup and Jaskolla explicitly leave it open to elaborate this general theist perspective on panpsychism in the direction of a panentheist perspective. The considerations above may contribute to ease this desideratum, and even show why it is promising to go this way: Panentheism consists in the thesis that »everything is in God «. Each of the concepts used in this thesis is in need of interpretation ${ }^{49}$. In the current, panpsychist context, severything can be specified as >every subject which exists and becomes in the course of natural evolution<. This is going to be abbreviated as >every natural subject<. Hence, also what is meant by >is in becomes clearer: to be in something for a subject means to be in a mental state in the sense mentioned in $\left(\mathrm{R}_{1}\right)$. Given this interpretation, panentheism seems to claim that every natural subject is in a mental state which is God, which in turn implies that God is a mental state, namely a mental state in which all natural subjects are. Does not this consequence amount to a reduction ad absurdum, bereaving God of His ontological independence and of His personality, since mental states seem to depend on their subjects and seem to be something different from persons?

The answer to this question is not necessarily positive, if we take into account the reshaping of the concept of a mental state provided by New Phenomenology. According to it, not every mental state is just a state of mind, let alone a state of mind borne or possessed by exactly one subject; on the contrary it is possible for a mental state to exist on its own, as an atmosphere in the sense given above and used also below. Nothing precludes that such an atmosphere is also a subject, or even a rational subject, i.e. a person. Therefore it is at least not absurd to understand God as the atmosphere of the universe and hence as the atmosphere of the different atmospheres encountering in it. This understanding, however, might run afoul of one horn of a well-known dilemma in the theological and philosophical discourse on $\operatorname{God}^{50}$ : On the one hand, God is a concrete agent within the universe, and as such somehow known to us-in this case by the way we know what it is like to be in an atmosphere. On the other hand, however, God is consistently conceived of as the »totally other« which should be referred to only in a negative or at least very cautious way. Understanding God as an atmosphere, does this not negate His transcendence, i.e. also His otherness exceeding human knowledge, which is expressed in that second horn? Shouldn't we all know the feeling what it is like to be in God?

However, what a feeling could that be? What is it like to be not (only) in some concrete atmosphere, but in any atmosphere at all? From the discussion on the limitation problem above, the answer to that is already known in an

49 Cf. Göcke 2015.

5o Cf. Brüntrup/Jaskolla 2017c: 929. 
abstract manner: What it is like to be in an atmosphere is the same as what it is like to be in space. If phenomenal bonding is possible in a way conceivable to us, this also is the fundamental content of the according mental states of the involved microsubjects. It may be surprising to assume that it is like something to be in space, that being in space is a qualitative perspective on the world, but this very assumption has been endorsed and elaborated by Immanuel Kant in a way which is pertinent to the present discussion ${ }^{51}$. For Kant, space is the pure form of external intuition ${ }^{52}$, whereby >external< characterizes the way the objects encountering in this way are intuitively apprehended: namely as different from the subject perceiving them. Accordingly, to be in space is to be confronted with something different from oneself. This intuition is not based on conceptual insight, which would be a privilege of rational subjects; on the contrary, it is the foundation of any sensual faculty and thereby can be presupposed to be at work wherever qualities are sensed. So even microsubjects below the human level need not lack the intuitive knowledge (in a minimal sense) that there is something different from them, e.g. something they can be addressed by, they can combine and form arrangements with. What it is like to be in space, understood thus, is being open to atmospheres, as something not identical with oneself but at the same time mental, and what can happen within them. This is what it is like to be a natural subject; this is like what it is to be in the mental state which is God. What it is like to be in that mental state, however, is different and therefore to be distinguished from what it is like to be that mental state, in this case: to be God. We know that difference only from one of its side ${ }^{53}$, namely from our side as human and therefore natural subjects: We know what it is like that we can encounter something (or someone) else, we know what it is like that there can be otherness. We can approach the other side of this difference at best in a negative way, like Nicolaus Cusanus did it by calling God, considered in Himself, non-aliud, the »Not-Other«, thus in the final analysis staying on our side of the difference (where else could we stay or go, at least under our natural conditions?) and acknowledging it as only one side of it.

These considerations allow to resume the initial question: Could it be the case that there is a metaphysical connection between panpsychism and panentheism? They even allow to give as a preliminary answer: Yes. This answer can be justified as follows: As suspected, the searched metaphysical

$5^{1} \quad$ For the following, cf. Voigt 2016.

$5^{2}$ Cf. Critique of Pure Reason: B42/A26.

53 On the conception of a difference with only one (available) relatum, see Zorn 2016: 119-129. 
connection consists in an experience which could not just be logically deduced. This experience in turn is the experience what, for natural subjects, it is like to be in space. It might be logically possible to think of possible worlds with natural subjects which lack the external intuition of space and therefore any feeling for the other-which also would be possible worlds without atmospheres. At the same time, it could turn out that these possible worlds widely differ from our actual world, since in them basic microsubjects might exist but, having no sense of something different from them, might never be able to combine and bring about macrosubjects. If every significant level of the physical world has its own mental inside, that would mean that such worlds without sense of otherness, without atmospheres would also lack significant physical structures above the level of the basic microsubjects. The way we experience our world tells us that it is very different from that. At the same time, since the inside of the microsubjects in our world are not directly accessible for us and since the concept of God as the atmosphere of atmospheres remains a borderline concept like the Cusanian >Non-Other, that difference does not force us to endorse the combination of panpsychism, New Phenomenology and panentheism offered here, let alone to assume the existence of such a God. The connection which has been argued for in this paper does not come along with metaphysical necessity, but rather with metaphysical possibility ${ }^{54}$, as it tries to make plausible what could be the case in any possible world resembling ours. The task to further explore this possibility seems to be quite alluring.

\section{References}

Böhme, G. (1995) Die Atmosphäre. Frankfurt am Main: Suhrkamp.

Brüntrup, G (2017) »Emergent Panpsychism.« In: Brüntrup, G., L. Jaskolla (eds.) Panpsychism. Contemporary Perspectives. Oxford: Oxford University Press, 48-71.

Brüntrup, G., L. Jaskolla (eds.) (2017a) Panpsychism. Contemporary Perspectives. Oxford: Oxford University Press.

Brüntrup, G., L. Jaskolla (2017b) »Introduction.« In: Brüntrup, G., L. Jaskolla (eds.) Panpsychism. Contemporary Perspectives. Oxford: Oxford University Press, 1-16.

Brüntrup, G., L. Jaskolla (2017c) »Panpsychismus und Handeln Gottes.« In: Gasser, G., L.Jaskolla, Th. Schärtl (eds.) Handbuch für analytische Theologie. Münster: Aschendorff.

54 For this conception, cf. Goff 2017a: 287-29o. 
Chalmers, D.J. (2017a) »Panpsychism and Panprotopsychism.« In: Brüntrup, G., L. Jaskolla (eds.), Panpsychism. Contemporary Perspectives. Oxford: Oxford University Press, 19-47.

Chalmers, D.J. (2017b) »The Combination Problem for Panpsychism.« In: Brüntrup, G., L. Jaskolla (eds.) Panpsychism. Contemporary Perspectives. Oxford: Oxford University Press, 179-214.

Coleman, S. (2017) »Panpsychism and Neutral Monism: How to Make up One's Mind« in: Brüntrup, G., L. Jaskolla (eds.) Panpsychism. Contemporary Perspectives. Oxford: Oxford University Press, 249-282.

Göcke, B. (2016) »There is no Panentheistic Paradigm.« The Heythrop Journal 57(6), online at: doi 10.1111/heyj.12314. Accessed: 2 June 2019.

Goff, P. (2017a) »The Phenomenal Bonding Solution to the Combination Problem.« In: Brüntrup, G., L. Jaskolla (eds.) Panpsychism. Contemporary Perspectives. Oxford: Oxford University Press, 283-302.

Goff, P. (2017b) Consciousness and Fundamental Reality. Oxford: Oxford University Press. Kripke, S. (1980) Naming and Necessity. Cambridge: Harvard University Press.

Leidenhag, J. (2018) Unity between God and Mind? A Study on the Relationship Between Panpsychism and Pantheism. In: Sophia 57 (2018): 1-18.

Meixner, U. (2004) The Two Sides of Being. A Reassessment of Psycho-Physical Dualism. Paderborn: Mentis.

Schmitz, H. (1981) System der Philosophie. Der Raum. Zweiter Teil. and edn. Bonn: Bouvier.

Schmitz, H. (1990) Der unerschöpfliche Gegenstand. Gründzüge der Philosophie. Bonn: Bouvier.

Schmitz, H. (1999) Der Spielraum der Gegenwart. Bonn: Bouvier.

Soentgen, J. (1998) Die verdeckte Wirklichkeit. Einführung in die Neue Phänomenologie von Hermann Schmitz. Bonn: Bouvier.

Soentgen, J. (2018) Ökologie der Angst. Berlin: Matthes \& Seitz.

Soentgen, J. (2019) »Eine Frage vorweg: Was sind Stoffgeschichten?« In: Soentgen, J. Konfliktstoffe. Über Kohlendioxid, Heroin und andere strittige Substanzen. München: Oekom, 17-52.

Swinburn, R. (2007) The Evolution of the Soul. Reprint of the revised edition. Oxford: Clarendon Press.

Voigt, U. (2016) »Raum und Gott—revisited.« In: Marschler, Th., Th. Schärtl (eds.), Eigenschaften Gottes. Ein Gespräch zwischen systematischer Theologie und analytischer Philosophie. Münster: Aschendorff, 117-127.

Voigt, U. (2019) »Wie ist es, ein Mikrosubjekt zu sein? Ein mesopsychistischer Versuch zum Thema Geist-Erfahrung.« In: M. Negele (eds.) Geist-Erfahrung. Würzburg: Königshausen \& Neumann, 41-58.

Zorn, D.-P. (2016) Vom Gebäude zum Gerüst. Entwurf einer Komparatistik reflexiver Figurationen in der Philosophie. Berlin: Logos. 